\title{
Estimated Reduction in Solids During Sheep Bedding Composting as a Function of the Composition of the Organic Fractions
}

Marco Antonio Previdelli Orrico Junior, Ana Carolina Amorim Orrico, Débora Maurício Manarelli, Walter Renato Teixeira Lopes \& Alice Watte Schwingel

To cite this article: Marco Antonio Previdelli Orrico Junior, Ana Carolina Amorim Orrico, Débora Maurício Manarelli, Walter Renato Teixeira Lopes \& Alice Watte Schwingel (2018) Estimated Reduction in Solids During Sheep Bedding Composting as a Function of the Composition of the Organic Fractions, Compost Science \& Utilization, 26:2, 91-97, DOI: 10.1080/1065657X.2017.1379916

To link to this article: https://doi.org/10.1080/1065657X.2017.1379916

\section{里 Published online: 05 Jan 2018.}

\section{Submit your article to this journal ๘}

山 Article views: 29

View Crossmark data 5 


\title{
Estimated Reduction in Solids During Sheep Bedding Composting as a Function of the Composition of the Organic Fractions
}

\author{
Marco Antonio Previdelli Orrico Junior ${ }^{\mathrm{a}}$, Ana Carolina Amorim Orrico ${ }^{\mathrm{a}}$, Débora Maurício Manarelli ${ }^{\mathrm{a}}$, \\ Walter Renato Teixeira Lopes ${ }^{\mathrm{a}}$, and Alice Watte Schwingel ${ }^{\mathrm{b}}$ \\ ${ }^{\mathrm{a} C o l l e g e ~ o f ~ A n i m a l ~ S c i e n c e s, ~ F e d e r a l ~ U n i v e r s i t y ~ o f ~ G r a n d e ~ D o u r a d o s, ~ D o u r a d o s, ~ M S, ~ B r a z i l ; ~}{ }^{\mathrm{b}}$ College of Agricultural Sciences, São Paulo State \\ University-"Júlio de Mesquita Filho" (UNESP), Fazenda Experimental Lageado, Botucatu, SP, Brazil
}

\begin{abstract}
The different organic matter fractions of residues significantly impact the degradability of organic material in composting windrows. Based on that, this study aimed to find out the organic matter fractions that most impact the breakdown rate during composting, besides proposing models to estimate the solids reductions in sheep bedding composting windrows. To that end, 24 sheep beddings from different locations and varied composition were composted so as to ensure the representativeness of the sample. The models found for reduction in total (TS) and volatile (VS) solids as a function of compostable organic matter (COM) and organic matter resistant to composting (OMRC) were not significant. Lignin had correlation coefficients of $-0.6,-0.89$, and -0.84 in relation to temperature, TS reduction, and VS reduction, respectively. The hemicellulose: lignin ratio was the parameter most correlated with temperature (0.69), TS reduction (0.91), VS reduction (0.92), and nitrogen (0.5), which led to more significant predictive models. It can be concluded that the hemicellulose:lignin ratio is the parameter that most impacts the breakdown of organic matter and nitrogen losses in sheep bedding composting windrows.
\end{abstract}

\section{Introduction}

Composting is one of the most used and disseminated techniques in Brazil for the treatment and recycling of solid residues from animal production (Orrico et al. 2012). Its main advantages are related to the reduction in the number of pathogenic microorganisms and volume and mass reduction of solids, in addition to generating at the end of the process an organic fertilizer rich in many important nutrients for plant growth (Moretti, Bertoncini, and Abreu-Junior 2013).

Composting is most often developed with the presence of fibrous agents (wood shavings and straw) in association with animal waste (Cayuela et al. 2012). The main advantages of using these agents are the reduction in greenhouse gas emissions during composting, reduction in nitrogen losses $(\mathrm{C} / \mathrm{N}$ ratio), ease of collection (for being solids), low odor emission, and low or no concentration of toxic components (Cayuela et al. 2012; Paradelo, Moldes, and Barral 2013).
Despite all those advantages, fibrous agents have some downsides, such as greater resistance to breakdown. The analyses of compostable organic matter (COM) and organic matter resistant to composting (OMRC), described by Kiehl (1985), have been used for many years in Brazil to predict the proportion of easyand hard-to-break down materials during composting. However, recent studies have shown that fractioning fiber into cellulose, hemicellulose, and lignin would be the safest way to predict the ease or difficulty of breaking down a certain plant material (Francou et al. 2008 and Nakhshiniev, Gonzales, and Yoshikawa 2012).

Francou et al. (2008) tested the degradability of different green waste mixes (high lignin content), biowaste (high contents of soluble carbohydrates and nitrogen), and paper-cardboard (high cellulose content) during the composting process. According to those authors, the presence of high proportions of lignin (windrows with higher proportions of green

CONTACT Marco Antonio Previdelli Orrico Junior marcoorrico@yahoo.com.br E College of Animal Sciences, Federal University of Grande Dourados, Dourados-MS, 79.804-970, Brazil.

Color versions of one or more of the figures in the article can be found online at www.tandfonline.com/ucsu. 
waste) negatively impacted organic matter stability. On the other hand, cellulose was shown to favor the rapid stabilization of organic matter up until 50\% paper-cardboard dry matter inclusion. Beyond that, the low nitrogen availability (very high $\mathrm{C} / \mathrm{N}$ ratio) reduced the breakdown of the material.

Confined animal bedding has a fibrous plant material base layer responsible for absorbing the excreta and food leftovers during confinement. The final product of such beddings is a nitrogen-rich (low $\mathrm{C} / \mathrm{N}$ ratio), very heterogeneous (depending on the ratio between excreta and bedding), partially broken-down material (bedding decomposition over confinement). That makes sheep bedding a very different material from those used in the aforementioned researches (Francou et al. 2008; Nakhshiniev, Gonzales, and Yoshikawa 2012).

Based on that, this study was conducted aiming to find out which organic matter fractions are most correlated with rate of breakdown during composting and subsequently propose models to explain the main changes in composting parameters for sheep bedding.

\section{Materials and Methods}

The research was developed based on different beddings collected in sheep confinements in the state of
Mato Grosso do Sul, Brazil. The beddings were collected from 24 different farms to ensure greater data representativeness.

The confinement areas were small, built in masonry, roofed, and well ventilated while the bedding base layer (absorbing material) was wood shavings. The difference among the farms lay on animal breeds and ages, diets provided, animal density, handling, and time each animal remained in confinement. All those differences allied to the large number of samples led to an important variability in data (table 1).

The sheep beddings collected in each property were transferred to a composting yard with concrete floor and $2 \%$ slope for excess moisture draining, being covered with a plastic sheet for protection against direct sunlight and rain. For the beginning of the experiment, an amount of approximately 20014;kg or 0.78 $\mathrm{m}^{3}$ bedding was established for the formation of each composting windrow, which resulted in windrows $0.714 ; \mathrm{m}$ high, $1.114 ; \mathrm{m}$ wide, and 1.414;m long. Three windrows were prepared for each collection site for a total of 72 experimental plots (windrows).

Temperature was recorded daily with a digital skewer thermometer inserted into the middle of the windrow. The mean windrow temperature data are presented in figure 1. The windrows were weighed

Table 1. Chemical and microbiological composition of the sheep beddings used to assemble the composting windrows.

\begin{tabular}{|c|c|c|c|c|c|c|c|c|c|c|c|}
\hline \multirow[b]{2}{*}{ Collection sites } & \multicolumn{9}{|c|}{$\%$ in TS } & \multicolumn{2}{|c|}{$\log$ MPN/g } \\
\hline & VS & $C$ & COM & OMRC & $\mathrm{N}$ & $\mathrm{C} / \mathrm{N}$ & Hem & CEL & Lig & $\mathrm{TC}$ & TTC \\
\hline 1 & 88.07 & 22.98 & 41.37 & 46.70 & 1.66 & 13.85 & 8.33 & 42.21 & 5.66 & 7.64 & 7.43 \\
\hline 2 & 88.43 & 23.91 & 43.05 & 45.38 & 1.64 & 14.58 & 8.33 & 42.67 & 6.12 & 8.23 & 7.98 \\
\hline 3 & 88.19 & 23.83 & 42.89 & 45.30 & 1.58 & 15.08 & 8.33 & 42.44 & 5.89 & 6.63 & 6.63 \\
\hline 4 & 88.00 & 24.65 & 44.37 & 43.63 & 1.55 & 15.90 & 8.36 & 42.81 & 6.14 & 7.65 & 7.34 \\
\hline 5 & 91.41 & 22.36 & 40.24 & 51.17 & 1.68 & 13.31 & 9.00 & 38.66 & 5.16 & 6.43 & 6.21 \\
\hline 6 & 90.37 & 21.78 & 39.21 & 51.16 & 1.65 & 13.20 & 9.00 & 39.12 & 5.62 & 7.63 & 7.21 \\
\hline 7 & 90.12 & 24.24 & 43.63 & 46.49 & 1.66 & 14.60 & 9.00 & 38.89 & 5.39 & 6.63 & 6.32 \\
\hline 8 & 91.45 & 21.89 & 39.41 & 52.04 & 1.60 & 13.68 & 9.03 & 39.24 & 5.64 & 7.63 & 7.34 \\
\hline 9 & 90.58 & 23.35 & 42.04 & 48.54 & 1.43 & 16.33 & 16.79 & 38.50 & 5.56 & 5.63 & 5.01 \\
\hline 10 & 90.65 & 22.03 & 39.65 & 51.00 & 1.44 & 15.30 & 16.79 & 38.95 & 6.02 & 5.36 & 5.36 \\
\hline 11 & 90.78 & 22.68 & 40.83 & 49.95 & 1.42 & 15.97 & 16.79 & 38.73 & 5.79 & 9.36 & 9.36 \\
\hline 12 & 91.02 & 22.72 & 40.89 & 50.13 & 1.38 & 16.46 & 16.84 & 39.08 & 6.04 & 9.61 & 8.92 \\
\hline 13 & 90.24 & 21.85 & 39.33 & 50.91 & 1.58 & 13.83 & 9.01 & 42.13 & 8.48 & 9.36 & 9.21 \\
\hline 14 & 90.13 & 24.49 & 44.09 & 46.04 & 1.55 & 15.80 & 9.01 & 42.59 & 8.94 & 8.36 & 8.36 \\
\hline 15 & 89.77 & 20.22 & 36.40 & 53.37 & 1.54 & 13.13 & 9.01 & 42.36 & 8.71 & 5.36 & 5.36 \\
\hline 16 & 90.02 & 23.30 & 41.94 & 48.08 & 1.50 & 15.53 & 9.04 & 42.72 & 8.97 & 7.63 & 7.63 \\
\hline 17 & 92.07 & 23.49 & 42.28 & 49.79 & 1.76 & 13.35 & 10.40 & 36.43 & 7.34 & 8.63 & 7.87 \\
\hline 18 & 92.04 & 23.13 & 41.64 & 50.40 & 1.81 & 12.78 & 10.40 & 36.89 & 7.80 & 6.63 & 6.23 \\
\hline 19 & 92.38 & 20.86 & 37.55 & 54.83 & 1.74 & 11.99 & 10.40 & 36.66 & 7.57 & 5.63 & 5.32 \\
\hline 20 & 92.21 & 24.24 & 43.64 & 48.57 & 1.73 & 14.01 & 10.43 & 37.01 & 7.82 & 7.63 & 7.16 \\
\hline 21 & 93.81 & 24.19 & 43.54 & 50.27 & 1.66 & 14.57 & 5.44 & 41.34 & 7.65 & 5.63 & 5.32 \\
\hline 22 & 93.56 & 21.71 & 39.08 & 54.48 & 1.63 & 13.32 & 5.44 & 41.80 & 8.11 & 8.63 & 7.63 \\
\hline 23 & 93.45 & 23.64 & 42.55 & 50.90 & 1.60 & 14.77 & 5.44 & 41.57 & 7.88 & 9.42 & 8.56 \\
\hline 24 & 93.90 & 22.75 & 40.94 & 52.96 & 1.59 & 14.31 & 5.46 & 41.93 & 8.13 & 7.80 & 7.80 \\
\hline
\end{tabular}

$\mathrm{C}=$ organic carbon; $\mathrm{N}=$ nitrogen; $\mathrm{C} / \mathrm{N}=$ carbon:nitrogen ratio; $\mathrm{COM}=$ compostable organic matter; $\mathrm{OMRC}=$ organic matter resistant to composting; $\mathrm{CEL}=$ cellulose; $\mathrm{HEMI}=$ hemicellulose; $\mathrm{LIG}=$ lignin; $\mathrm{TC}=$ total coliforms, and $\mathrm{TTC}=$ thermotolerant coliforms. 


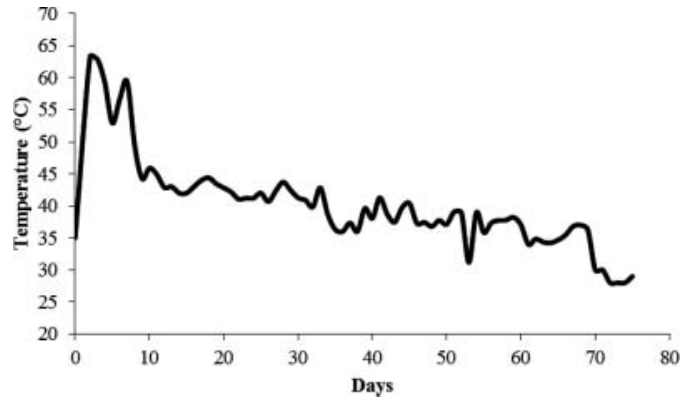

Figure 1. Behavior of mean windrow temperature during sheep bedding composting.

weekly to follow the reductions in total solids (TS) and volatile solids (VS) and to maintain the moisture content in the windrows between 50 to $60 \%$. Samples were collected during the weekly weighings to determine moisture, which, along with windrow weight, enabled calculating the amount of water to be added to the windrow to reach the maximum moisture content of $60 \%$. Water was added and slowly mixed in the windrows to prevent slurry formation. This was done weekly for all windrows in order to keep their moisture content from varying much, which might impact the result of the study.

The windrows were turned over and weighed once a week. Contents of carbon (C), nitrogen (N), compostable organic matter (COM), organic matter resistant to composting (OMRC), neutral detergent fiber (NDF), acid detergent fiber (ADF), cellulose, hemicellulose, lignin, $\mathrm{C} / \mathrm{N}$ ratio, and most probable number (MPN) of total (TC) and thermotolerant coliforms (TTC) were measured at the beginning and end of the process (78 days).
Measurements of TS, VS, and MPNs of TC and TTC during composting were determined for each sample according to the methodology described by APHA (2005). The contents of COM and OMRC organic C were estimated as proposed by Kiehl (1985). The concentrations of total nitrogen, cellulose, hemicellulose, and lignin were determined according to the methodology described by Silva and Queiroz (2006).

Data were analyzed using the package $\mathrm{R}$ (version 2.15.2 for Windows) and underwent Shapiro-Wilk's test for residual normality, and Bartlett's test for variance homogeneity. The presence of outliers was also verified. All characteristics met the assumptions of the model. After preliminary analysis, regression analyses were performed between sheep bedding component content (independent variables) and composting characteristics (dependent variables).

Spearman correlation (agricolae package, version 1.1-4) was used to assess the association between sheep bedding composition (independent variables) and composting characteristics (dependent variables) at a significance level of $95 \%$.

\section{Results and Discussion}

Table 2 displays important correlations between sheep bedding composition and composting efficiency. Among the different fractions making up the initial material, hemicellulose responded more positively and lignin, more negatively. Therefore, the hemicelluloseto-lignin ratio was taken as parameter showing the most significant correlations.

Table 2. Correlation coefficients between the sheep litter composition and the main parameters assessed during composting.

\begin{tabular}{|c|c|c|c|c|c|c|c|}
\hline Parameters & \multicolumn{7}{|c|}{ Windrow composition (\% in TS) } \\
\hline $\mathrm{T}\left({ }^{\circ} \mathrm{C}\right)$ & ns & ns & ns & $0.44^{* *}$ & ns & $-0.60^{* *}$ & $0.69^{* * *}$ \\
\hline Red TS (\%) & ns & $-0.48^{* *}$ & ns & $0.43^{*}$ & ns & $-0.89^{* * *}$ & $0.91^{* * *}$ \\
\hline Red VS (\%) & ns & $-0.39^{*}$ & $0.41^{*}$ & $0.46^{* *}$ & ns & $-0.84^{* * *}$ & $0.92^{* * *}$ \\
\hline $\operatorname{Red} C(\%)$ & $0.54^{* *}$ & $-0.74^{* * *}$ & $0.51^{* *}$ & ns & ns & $-0.38^{*}$ & $0.74^{* * *}$ \\
\hline Red COM (\%) & $0.54^{* *}$ & $-0.74^{* * *}$ & $0.51^{* *}$ & ns & ns & $-0.38^{*}$ & $0.74^{* * *}$ \\
\hline Red OMRC (\%) & ns & ns & ns & $0.45^{* *}$ & ns & $-0.38^{*}$ & $0.63^{* * *}$ \\
\hline Red N (\%) & ns & ns & ns & ns & ns & ns & $0.50^{* *}$ \\
\hline Red Hemi (\%) & ns & ns & ns & $0.80^{* * *}$ & $-0.58^{* *}$ & $-0.83^{* * *}$ & $0.76^{* * *}$ \\
\hline Red Cel (\%) & ns & ns & ns & $0.54^{* *}$ & ns & $-0.81^{* * *}$ & $0.59^{* *}$ \\
\hline Red Lig (\%) & ns & ns & ns & $0.40^{*}$ & ns & $-0.46^{* *}$ & $0.74^{* * *}$ \\
\hline Red TC (\%) & ns & ns & ns & ns & ns & ns & ns \\
\hline Red TTC (\%) & ns & ns & ns & ns & ns & ns & ns \\
\hline
\end{tabular}

$\mathrm{ns}=$ not significant;

* $=p<0.05$;

$* *=p<0.01$;

${ }^{* * *}=p<0.001$ 
Temperature is important for composting quality (Alexander 2007). High temperatures for a long period increase material breakdown and, thus, its rate to reach a stable form will be slower (Flynn and Wood 1996). The higher the temperature, the higher the reduction in pathogenic microorganisms that cannot tolerate high temperatures for several days (Torres et al. 2007). The windrows originated from sheep bedding with higher $\mathrm{Hemi} / \mathrm{lig}$ ratios had the highest average temperature during composting. However, no significant correlations or significant models were found between sheep bedding compositions and reductions in total and thermophilic coliforms. All windrows had TC and TTC reductions above $99.99 \%$ since all of them achieved average temperatures of $55^{\circ} \mathrm{C}$ during the thermophilic phase. Such high temperatures lasted for more than 30 days (thermophilic phase), thus destroying much of the coliforms. According to Orrico, Orrico Junior, and Lucas Junior (2007), temperatures over $55^{\circ} \mathrm{C}$ for 21 consecutive days are sufficient to lower pathogens to acceptable levels, thus enabling the application of organic residues to the soil. Authors such as Curci et al. (2007) and Torres et al. (2007) demonstrated the effectiveness of composting in eliminating several species of pathogenic microorganisms, including sporulating bacteria such as Clostridium sp.

Figure 2 shows the behavior of OMRC and COM contents for TS and VS reductions. Even though widely used to characterize a composting residue, these parameters showed no models $(p>0.05)$ able to explain the behavior of TS and VS reduction in the windrows. Thus, the use of OMRC and COM to predict the breakdown of fiber-rich residues has low accuracy and their use is not indicated.
Fiber fractioning enabled identifying lignin and its proportion to other fiber fractions as general agent of composting material breakdown (figure 3). Moreover, Francou et al. (2008) concluded that, among the fibrous fractions, lignin most influences delaying organic matter decomposition, thus the rate of biodegradation of an organic material varies with its lignin content. Therefore, Francou et al. (2008) stated the (cellulose + hemicellulose)/lignin ratio is a reliable predictor of breakdown potential or even whether it has already reached a satisfying level of degradation to be used as organic fertilizer. According to those authors, the higher the (cellulose + hemicellulose)/lignin ratio, the higher the material biodegradation.

Furthermore, lignin had a negative effect on TS and VS reductions. However, the most significant model with the highest $R^{2}$ value was the one relating reductions in TS and VS to the Hemi/lig ratio. This variable also showed the best correlation coefficients and was the most suitable to estimate breakdown of the material used in this study.

Interestingly, cellulose and hemicellulose reductions were also influenced by lignin contents, as well as the Hemi/lig and (cellulose + hemicellulose)/lignin ratios in composting starting material (figure 4). Orrico et al. (2012), when studying composting with different poultry litter materials, observed that the highest reductions in cellulose and hemicellulose (77.37 and $74.23 \%$, respectively) were obtained in the litters that had the lowest lignin contents. This finding is in agreement with the study carried out by Perez et al. (2002), who found that lignin, besides being poorly degraded, also contributes to delaying the biodegradation of plant material cellulose and hemicellulose, hence playing a role as physical barrier and protecting fibers from the attack of cellulolytic
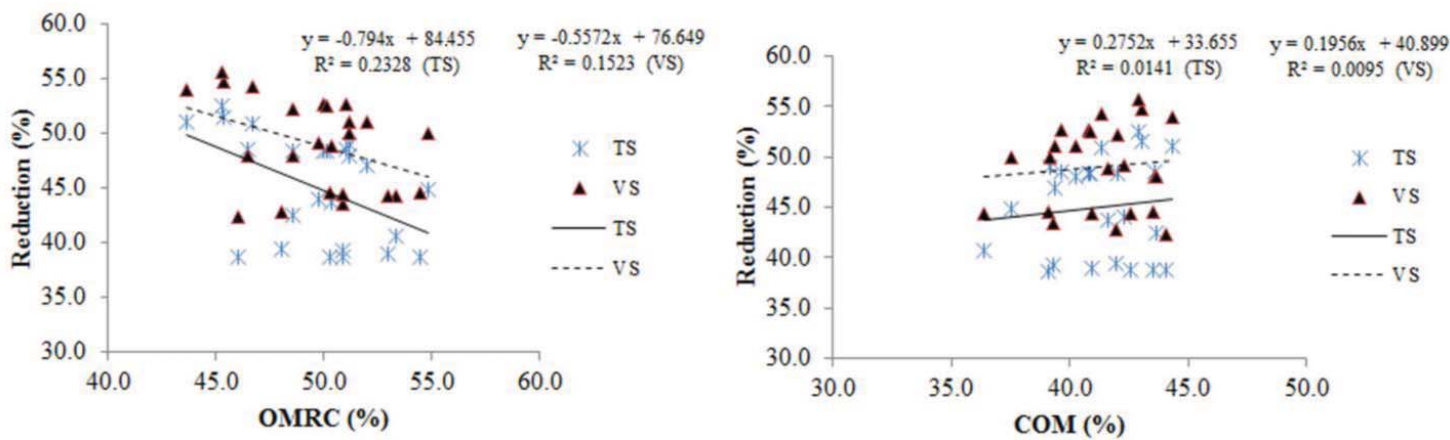

Figure 2. Behavior of TS and VS reductions according to the contents of COM and OMRC. Significance: $p<0.05$. 

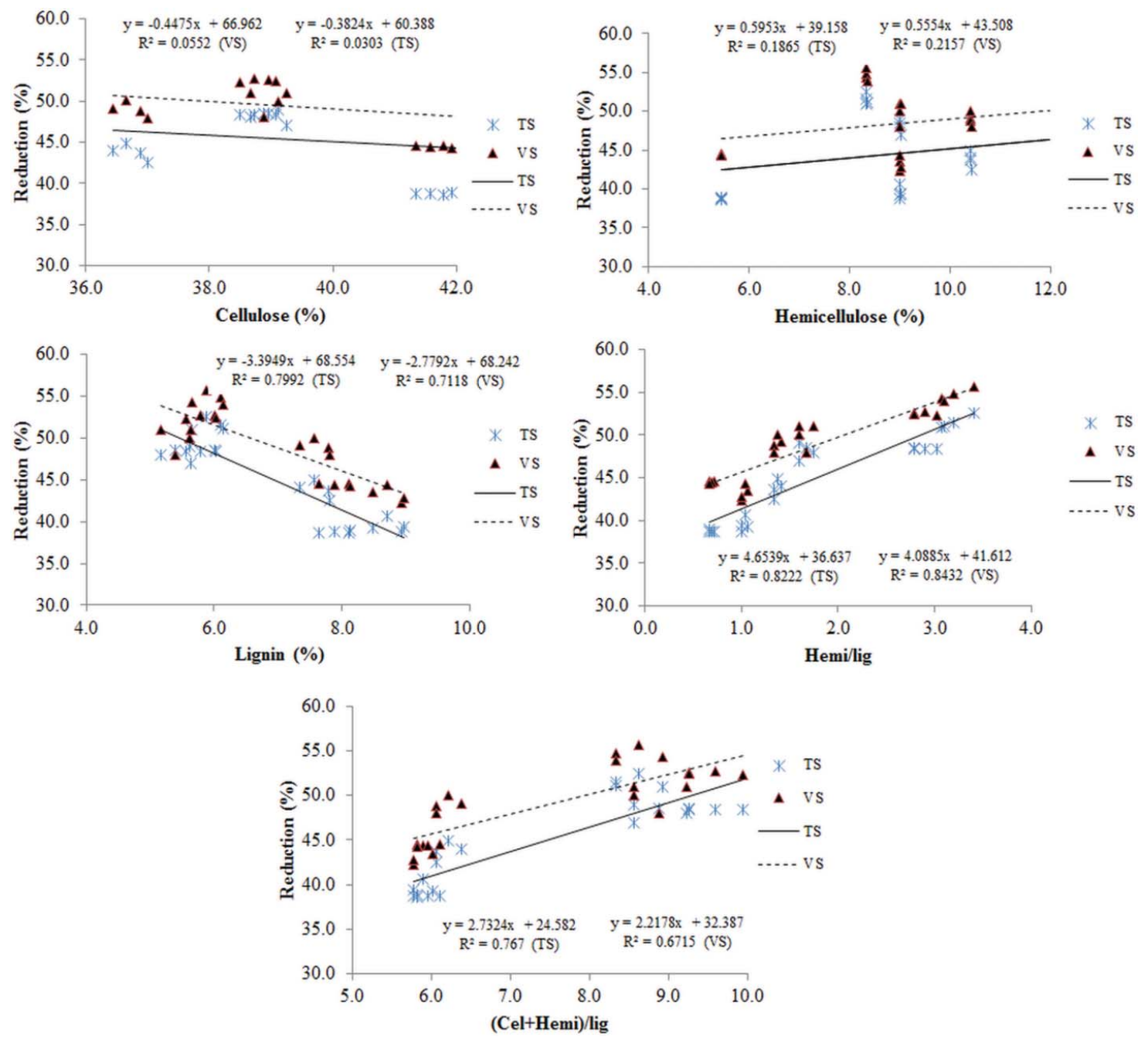

Figure 3. Behavior of TS and VS reductions according to the contents of cellulose $\left(p_{\mathrm{ts}}=0.082\right.$ and $\left.p_{\mathrm{vs}}=0.077\right)$, hemicellulose $\left(p_{\mathrm{ts}}=0.052\right.$ and $\left.p_{\mathrm{vs}}=0.051\right)$, lignin $\left(p_{\mathrm{ts}}=0.002\right.$ and $\left.p_{\mathrm{vs}}=0.002\right)$, and Hemi/lig $\left(p_{\mathrm{ts}}<0.001\right.$ and $\left.p_{\mathrm{vs}}=0.001\right)$ and (cellulose+hemicellulose)/lignin $\left(p_{\mathrm{ts}}=0.002\right.$ and $p_{\mathrm{vs}}=0.003$ ) ratios.

and hemicellulolytic microorganisms. Thus, it is believed that part of the hemicellulose and cellulose susceptible to breakdown was not hydrolyzed during composting due to strong protection by lignin.

Nitrogen reduction was influenced $(p<0.01)$ only by the Hemi/lig ratio (figure 5). According to Orrico Junior, Orrico, and Lucas Junior (2010), significant nitrogen losses are commonly observed during composting of residues with low $\mathrm{C} / \mathrm{N}$ ratios. This is explained by a $\mathrm{C} / \mathrm{N}$ ratio imbalance in the material, which, in most cases, experiences excess nitrogen loss through volatilization as ammonia. These losses start with nitrogenous compound hydrolysis by microorganisms breaking down organic $\mathrm{N}$ to form $\mathrm{N}-\mathrm{NH}_{4}{ }^{+}$ (ammonification). The $\mathrm{N}-\mathrm{NH}_{4}{ }^{+}$formed is used for microbial growth or nitrification process; however, in amounts above microorganism absorption, it is lost to the atmosphere as nitrogen and ammonia oxides, with the latter representing the largest fraction (Steiner et al. 2010). In this specific study, treatments with the highest breakdown rates (higher Hemi/lig ratios) promoted the largest nitrogen losses. That contrasts with a study developed by Orrico et al. (2012), who stated that the highest breakdown rates were achieved by materials with the lowest $\mathrm{N}$ reductions due to microbial activity, which prevents $\mathrm{N}$ losses to the atmosphere. Such discrepancy in results might have derived from a low $\mathrm{N}$ content in the source used here (1.38 to $1.81 \%$ ), much lower than the one used by those authors (3.15 to 3.65\%). Thus, the higher microbial activity induced higher nitrogen volatilization in the windrows. 

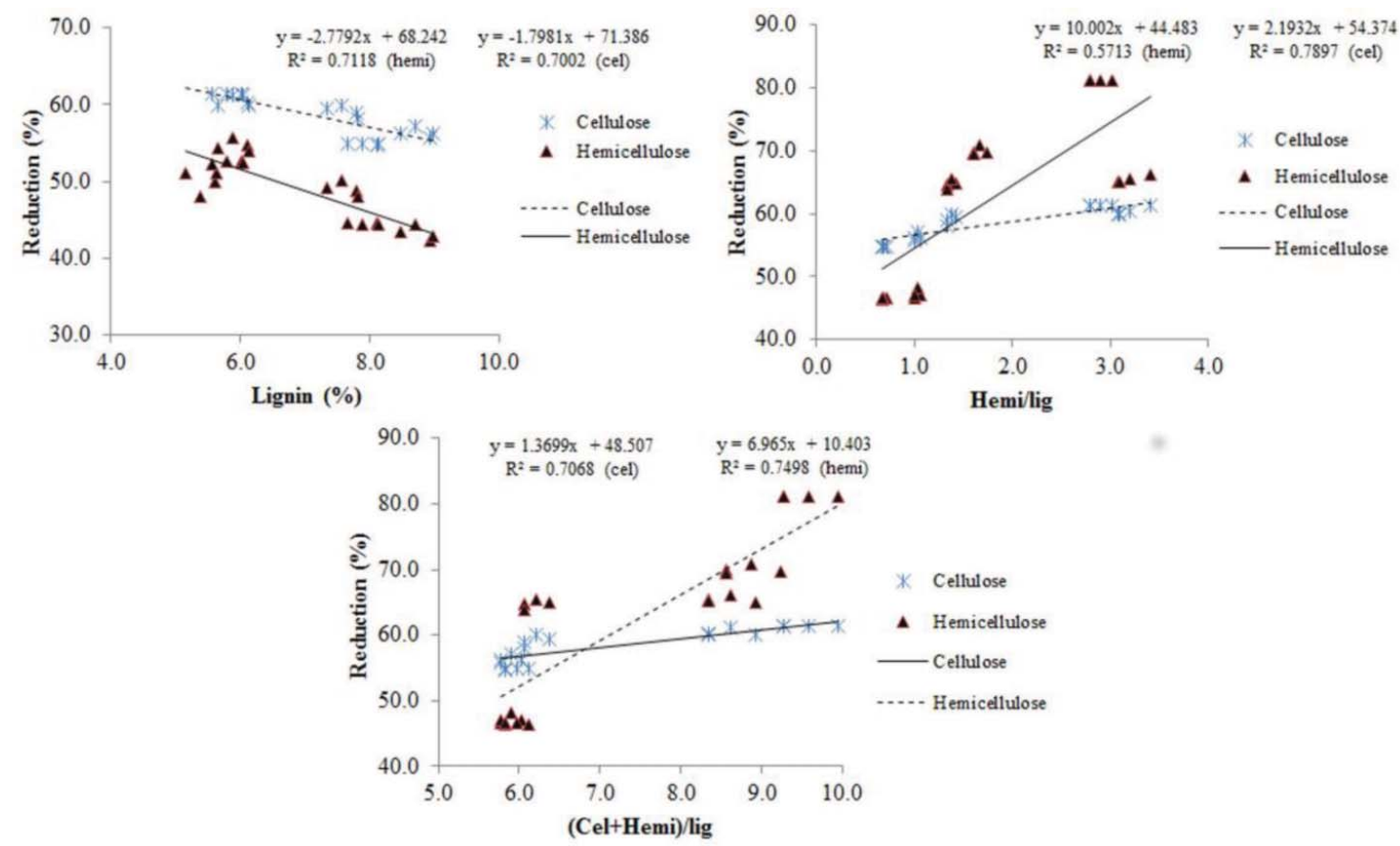

Figure 4. Behavior of cellulose and hemicellulose reductions according to the contents of lignin and Hemi/lig and (cellulose+hemicellulose)/lignin ratios. Significance: $p<0.01$.

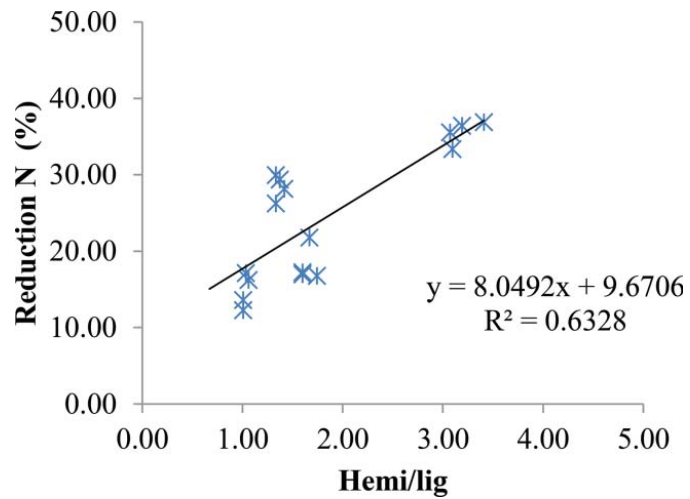

Figure 5. Behavior of nitrogen reductions according to Hemi/lig ratios. Significance: $p<0.01$.

\section{Conclusion}

Among the various organic fractions in plant residues, the Hemi/lig ratio is the one that primarily influences windrow temperature and reductions in solids and nitrogen of sheep beddings; thus, it is considered the most important characteristic of a composting material.

\section{References}

Alexander, P. D. 2007. Effect of turning and vessel type on compost temperature and composition in backyard (amateur) composting. Compost Science \& Utilization 15 (3):167-75. https://doi.org/10.1080/1065657X.2007.1070 2329.

American Public Health Association (APHA). 2005. Standard methods for examination of water and wastewater, 1-1368. Washington: American Water Works Association.

Cayuela, M. L., M. A. Sánchez-Monedero, A. Roig, T. Sinicco, and C. Mondini. 2012. Biochemical changes and GHG emissions during composting of lignocellulosic residues with different N-rich by-products. Chemosphere 88:193203. https://doi.org/10.1016/j.chemosphere.2012.03.001.

Curci, V. C. L. M., I. S. Dutra, J. Döbereiner, and J. Lucas Junior. 2007. Pré-compostagem de cadáveres de bovinos acometidos pelo botulismo. Pesq. Vet. Bras 27 (4):157-61. https://doi.org/10.1590/S0100-736X2007000400005.

Flynn, R. P., and C. W. Wood. 1996. Temperature and chemical changes during composting of broiler litter. Compost Science \& Utilization 4 (3):62-70. https://doi.org/10.1080/ 1065657X.1996.10701841.

Francou, C., M. Linères, S. Derenne, M. Villio-Poitrenaud, and S. Houot. 2008. Influence of green waste, biowaste and paper-cardboard initial ratios on organic matter transformations during composting. Bioresource Technology 99 (3):8926-34. https://doi.org/10.1016/j.biortech.2008.04.071.

Kiehl, E. J. 1985. Fertilizantes orgânicos, 1-492. São Paulo: Agronômica Ceres.

Moretti, S. M. L., E. I. Bertoncini, and C. H. Abreu-Junior. 2013. Aplicação do método de mineralização de nitrogênio com lixiviação para solo tratado com lodo de esgoto e composto orgânico. Revista Brasileira Ciências do Solo 37 (3):622-31. https://doi.org/10.1590/S0100-06832013000300008. 
Nakhshiniev, B., H. B. Gonzales, and K. Yoshikawa. 2012. Hydrothermal treatment of date palm lignocellulose residue for organic fertilizer conversion: Effect on cell wall and aerobic degradation rate. Compost Science \& Utilization 20 (4):245-53. https://doi.org/10.1080/1065657X.2012.10737055.

Orrico Junior, M. A. P., A. C. A. Orrico, and J. Lucas Junior. 2010. Compostagem dos resíduos da produção avícola: Cama de frangos e carcaças de aves. Engenharia Agrícola 30 (3):538-45. https://doi.org/10.1590/S010069162010000300017.

Orrico Junior, M. A. P., A. C. A. Orrico, J. Lucas Junior, A. A. M. Sampaio, A. R. M. Fernandes, and E. A. Oliveira. 2012. Compostagem dos dejetos da bovinocultura de corte: Influência do período, do genótipo e da dieta. Revista Brasileira de Zootecnia 41 (5):1301-7. https://doi.org/10.1590/S151635982012000500030.

Orrico, A. C. A., M. A. P. Orrico Junior, and J. Lucas Junior. 2007. Alterações físicas e microbiológicas durante a compostagem dos dejetos de cabras. Engenharia Agrícola 27 (3):764-72. https://doi.org/10.1590/S010069162007000400020.

Orrico, A. C. A., S. R. Centurion, R. M. de Farias, M. A. P. Orrico Junior, and R. G. Garcia. 2012. Effect of different substrates on composting of poultry litter. Revista Brasileira de Zootecnia 41 (7):1764-8. https://doi.org/10.1590/S151635982012000700028.

Paradelo, R., A. B. Moldes, and M. T. Barral. 2013. Evolution of organic matter during the mesophilic composting of lignocellulosic winery wastes. Journal Environmental Manage 116:18-26. https://doi.org/10.1016/j.jenvman. 2012.12.001.

Perez, J., J. Muñoz-Dorado, T. Rubia, and J. Martínez. 2002. Biodegradation and biological treatments of cellulose, hemicellulose and lignin: An overview. International Microbiology 5 (2):53-63. https://doi.org/10.1007/s10123-0020062-3.

Silva, D. J., and A. C. Queiroz. 2006. Análise de alimentos: Métodos químicos e biológicos, 1-166. 3rd ed. Viçosa: UFV.

Steiner, C., K. C. Das, N. Melear, and D. Lakly. 2010. Reducing nitrogen loss during poultry litter composting using biochar. Journal of Environmental Quality 39 (4):1236-42. https://doi.org/10.2134/jeq2009.0337.

Torres, P., A. Pérez, J. P. Escobar, I. E. Uribe, and R. Imery. 2007. Compostaje de biosólidos de plantas de tratamiento de águas residuales. Engenharia Agrícola 27 (1):267-75. https://doi.org/10.1590/S0100-69162007000100021. 